\title{
GONADOTROPHIN-INDUCED MULTIPLE OVULATION IN THE CRAB-EATING MONKEY, MACACA FASCICULARIS
}

\author{
M. R. JAINUDEEN* AND E. S. E. HAFEZ \\ Departments of Gynecology-Obstetrics and Physiology, \\ Wayne State University School of Medicine, Detroit, Michigan 48201, U.S.A.
}

(Received 15th October 1972)

Summary. Two treatments of PMSG and HCG were used to induce multiple ovulation in nine adult crab-eating monkeys (Macaca fascicularis). The number of ovulations ranged from one to eight. Eggs were recovered from the oviducts of three untreated monkeys. Failure to recover eggs from gonadotrophin-treated monkeys was partly due to failure of the ruptured follicle to release the egg.

Primate gonadotrophins given in combination with HCG have been successfully used to induce multiple ovulation in prepubertal, cyclic and hypophysectomized rhesus monkeys (Macaca mulatta), but the ability of gonadotrophins of nonprimate origin, such as PMSG or sheep pituitary preparations, to induce ovulation has been disappointing (cf. van Wagenen, 1968). This failure has been attributed to species-specificity of primate pituitary hormones (Knobil, Kostyo \& Greep, 1959). Since a combination of PMSG and HCG consistently induced multiple ovulation in the squirrel monkey (Saimiri sciureus) (Bennett, 1967; Dukelow, 1970), a comparable study was undertaken in the crab-eating monkey (Macaca fascicularis).

Six cycling and three amenorrhoeic monkeys were injected intramuscularly with PMSG (Equinex, Ayerst) and HCG (APL, Ayerst) using two treatment schedules (Table 1). The first day of menstrual bleeding was considered as Day 1. An additional three cycling monkeys served as untreated controls.

On Days 12, 14 and 16, serial laparotomies or laparoscopies were performed under ketamine hydrochloride (Ketaset, Bristol Labs, N.Y.) analgesia.

In control animals, only one Graafian follicle reached preovulatory size (5 to $8 \mathrm{~mm}$ ). By contrast, the ovaries of gonadotrophin-treated monkeys showed either several small follicles ( 2 to $3 \mathrm{~mm}$ ) or six to eight large follicles ( 5 to $8 \mathrm{~mm}$ ) surrounded by a thin rim of luteal tissue (Pl. 1, Figs 1 and 2). The ovulation sites in controls appeared as distinct protuberances (Pl. 1, Fig. 6), while, in treated animals, they appeared as dome-shaped structures protruding from the ovarian surface (Pl. 1, Figs 3 and 5), or as raised points on the follicular surface (Pl. 1, Fig. 4).

The results presented in Table 1 were based on inspection of ovulation points

* Present address: Faculty of Veterinary Science, University of Ceylon, Peradeniya, Geylon. 
and subsequent confirmation of CL tissue by histological examination on Day 22. Single ovulations occurred in three control monkeys between Days 12 and 14. In cycling monkeys, gonadotrophin-induced multiple ovulations occurred in four females and a single ovulation in two. In amenorrhoeic animals, one responded with a single ovulation and two failed to ovulate although multiple follicular development was induced The addition of 125 i.u. PMSG to the

Table 1. Ovarian response in Macaca fascicularis treated with PMSG and HCG

\begin{tabular}{|c|c|c|c|c|c|c|}
\hline \multicolumn{2}{|l|}{ Treatment } & $\begin{array}{c}\text { Monkey } \\
\text { no. }\end{array}$ & $\begin{array}{c}\text { No. of follicles } \\
\text { of } 3 \text { to } 8 \mathrm{~mm}\end{array}$ & $\begin{array}{l}\text { No. of } \\
\text { ovulations }\end{array}$ & $\begin{array}{l}\text { No. of luteinized } \\
\text { follicles }\end{array}$ & $\begin{array}{c}\text { Ovulation } \dagger \\
(\%)\end{array}$ \\
\hline $\begin{array}{l}\text { PMSG, } 250 \text { i.u. } \\
\text { (Day } 5 \text { to } 10)\end{array}$ & & 1 & 10 & 4 & 0 & 40 \\
\hline $\begin{array}{l}\text { PMSG, } 125 \text { i.u. } \\
\text { (Day 11 to 13) }\end{array}$ & A & 2 & 9 & 1 & 6 & 11 \\
\hline $\begin{array}{l}\text { HCG, } 2000 \text { i.u. } \\
\text { (Day } 11 \text { to } 13 \text { ) }\end{array}$ & & 3 & 8 & 1 & 4 & 12 \\
\hline $\begin{array}{l}\text { PMSG, } 250 \text { i.u. } \\
\text { (Day } 5 \text { to } 10)\end{array}$ & & 4 & 6 & 5 & 0 & 85 \\
\hline HCG, $\stackrel{+}{2000}$ i.u. $\}$ & B & & & & 4 & 62 \\
\hline (Day 11 to 13 ) & & $\begin{array}{l}6 \\
7^{*} \\
8^{*} \\
9^{*}\end{array}$ & $\begin{array}{r}10 \\
5 \\
6 \\
4\end{array}$ & $\begin{array}{l}7 \\
0 \\
0 \\
1\end{array}$ & $\begin{array}{l}3 \\
3 \\
5 \\
3\end{array}$ & $\begin{array}{r}70 \\
0 \\
0 \\
25\end{array}$ \\
\hline
\end{tabular}

* Animals with a history of amenorrhoea were injected subcutaneously with $5.0 \mathrm{mg}$ progesterone for 4 days and were placed on Treatment $B 3$ days later.

$\uparrow$ Number of ovulation points as a percentage of the number of follicles 3 to $8 \mathrm{~mm}$ in diameter.

HCG injections (Treatment A) failed to induce multiple ovulation in two animals, due to the formation of large cystic follicles.

Ovulation occurred in six out of seven gonadotrophin-treated monkeys between Days 12 and 16. There was much individual variation in the times of the first and subsequent ovulations among and within monkeys. For example, in Monkey 6, one ovulation occurred on the left ovary on Day 12 and four additional ovulation points were seen on the right ovary on Day 16 (PI. 1, Figs 3 and 4). The induced CL and luteinized follicles could be identified at Day 22. These luteinized follicles consisted of fluid-filled cavities lined by a thin

\section{EXPLANATION OF PLATE 1}

Ovaries of gonadotrophin-treated crab-eating monkeys (Macaca fascicularis).$\times 4$.

Frgs 1 and 2. Monkey 1, left ovary: multiple follicles (Day 11) and luteinized follicles (Day 22).

FIG. 3. Monkey 6, left ovary: one ovulation point and a cystic follicle (Day 12). Two additional ovulation points are located on the opposite surface.

Fig. 4. Monkey 6, right ovary: four ovulation points and one mature follicle (Day 16). Fig. 5. Monkey 5, left ovary: three ovulation points (background) and a haemorrhagic follicle (foreground) (Day 16).

Fig. 6. Control monkey, right ovary: one ovulation point (Day 12); a one-cell egg in cumulus clot was recovered from the oviduct. 


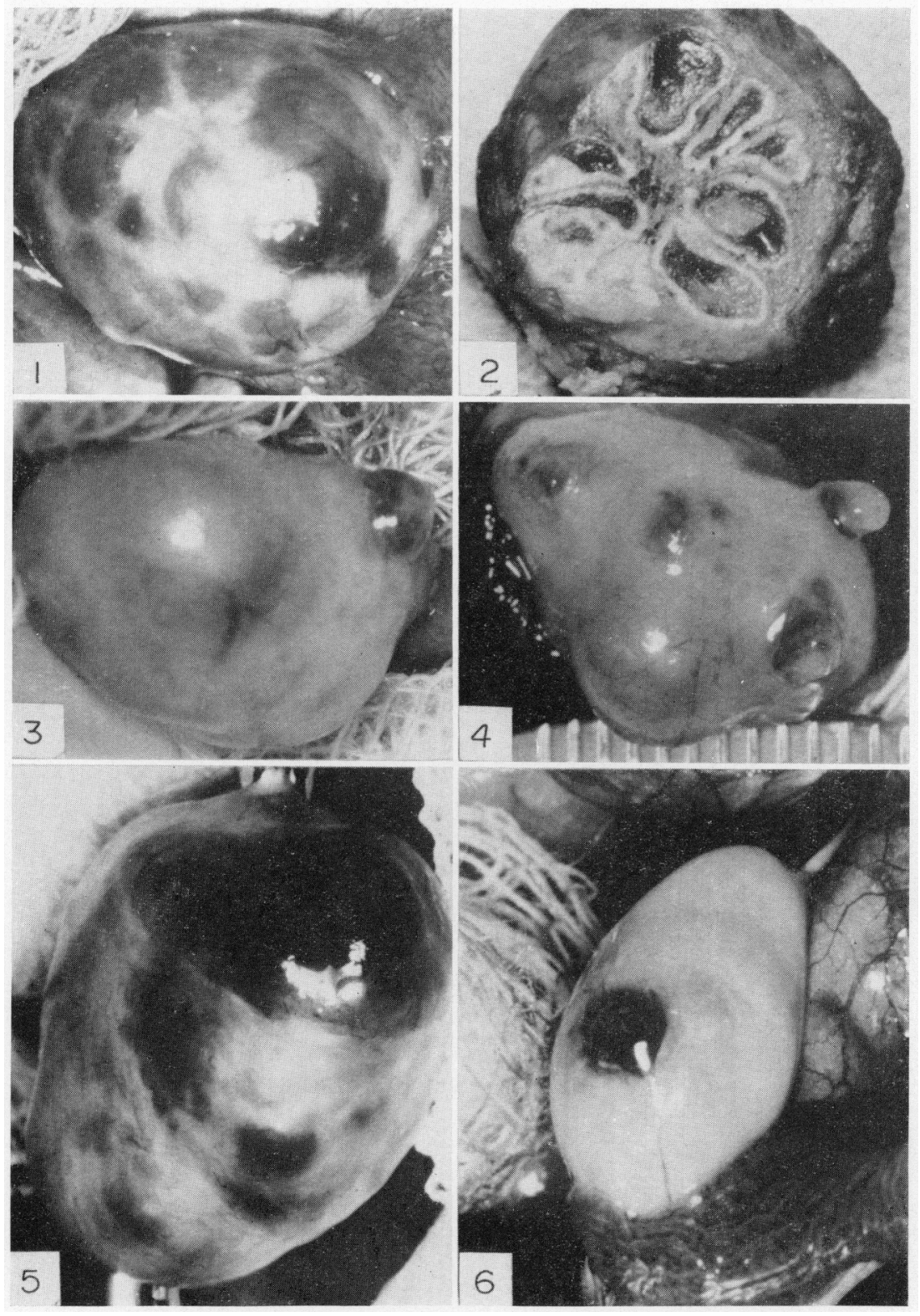



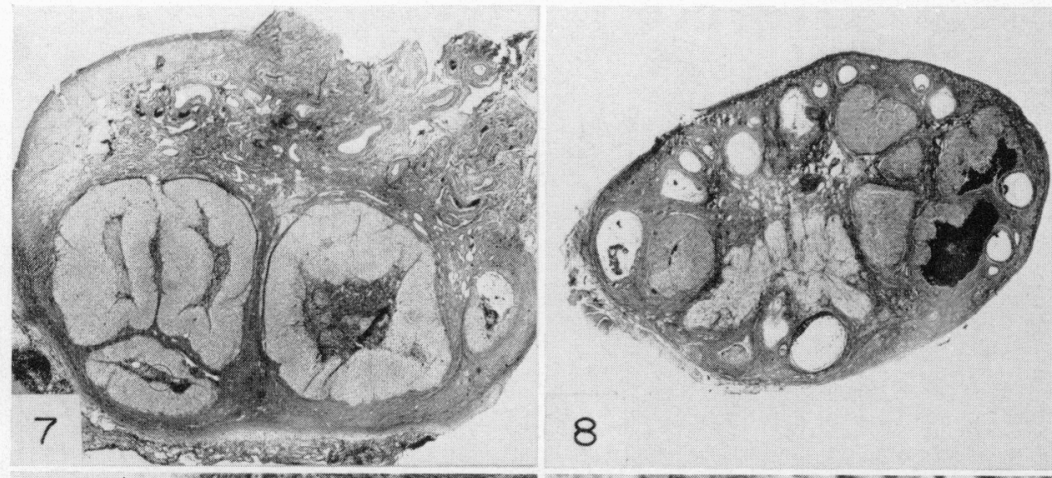

8
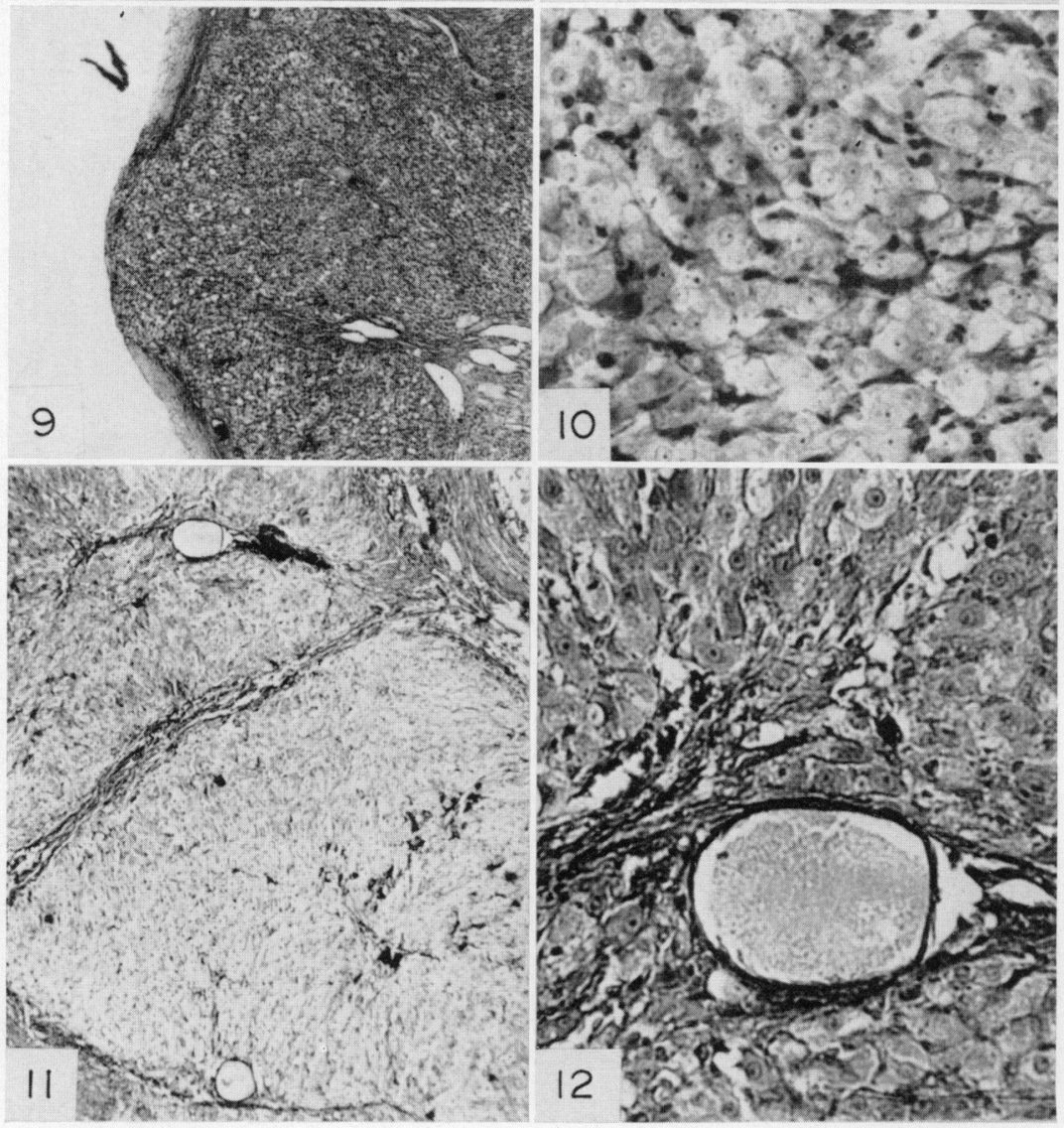

(Facing p. 153) 
rim of luteal tissue (Pl. 1, Fig. 2). The dose-response relationship for PMSG in terms of number of ovulations is similar to that reported for human menopausal gonadotrophin (HMG) in rhesus monkeys (Mastroianni \& Rosseau, 1965; van Wagenen, 1968). However, the number of unruptured follicles is greater with PMSG.

The recovery of eggs would be the most valid criterion of ovulation in nonhuman primates. Instances of induced multiple ovulation in the rhesus monkey (van Wagenen \& Simpson, 1957; Knobil et al., 1959; Simpson \& van Wagenen, 1962) were based on ovulation points and identification of induced CL. Only a few eggs were recovered from gonadotrophin-treated rhesus monkeys (Mastroianni \& Rosseau, 1965; Breckwoldt, Bettendorf \& Garcia, 1971) or squirrel monkeys (Bennett, 1967). In the present study, although eggs were recovered from the oviducts of three controls 1 to 3 days after ovulation, none were recovered from the oviducts of treated monkeys. The uterus was not searched for eggs.

Poor recovery of eggs from gonadotrophin-treated monkeys is believed to be due to accelerated transport of oviducal eggs or to a failure of the fimbriae to pick up eggs from the greatly enlarged ovaries. Of interest, however, is the trapping of eggs within ruptured follicles with HMG treatment in rhesus monkeys (van Wagenen \& Simpson, 1957; Knobil et al., 1959). The results of the present study show that failure to recover eggs in three out of four animals with multiple CL (Pl. 2, Figs 1 to 4) was partly due to trapping of eggs within the ruptured follicles. For example, in Monkey 5, eight eggs were trapped within the luteal tissue (Pl. 2, Figs 5 and 6). Eggs were also seen lying free in the cavities of luteinized follicles.

One reason for treating monkeys with PMSG was to obtain fertilized ova for studies in vitro. It is evident, however, that the treatments employed had a deleterious effect on the ovulatory mechanism and/or oviducal physiology.

This study was supported in part by a grant from The Ford Foundation, No. 710-0281. Thanks are due to Dr S. A. Lindsay, of Ayerst Labs, N.Y., for a donation of Equinex and APL, and to Bristol Labs, N.Y., for a donation of Ketaset.

\section{REFERENGES}

BenNetT, J. P. (1967) The inuuction of ovulation in the squirrel monkey (Saimiri sciureus) with pregnant mares serum (PMS) and human chorionic gonadotrophin (HCG). 7. Reprod. Fert. 13, 357.

Breckwoldt, M., BetTendorf, G. \& Garcia, G. S. (1971) Induction of ovulation in non-cycling and hypophysectomized rhesus monkeys with various gonadotropins. Fert. Steril. 22, 451.

\section{EXPLANATION OF PLATE 2}

Photomicrographs of histological sections of the ovaries of gonadotrophin-treated crabeating monkeys (Macaca fascicularis) (Day 22).

Figs 7 and 8 . Multiple corpora lutea. $\times 6$.

FIc. 9. One of the multiple corpora lutea cut through the stigma $\times 160$.

Fig. 10. Higher magnification of a corpus luteum. $x 400$.

Fig. 11. Two corpora lutea in the ovary of a monkey from which no eggs were recovered.

Note two trapped eggs within the luteal tissue. $\times 160$.

FIG. 12. Higher magnification of a trapped egg. $\times 400$. 
DukeLow, W. R. (1970) Induction and timing of single and multiple ovulations in the squirrel monkey (Saimiri sciuresus). 7. Reprod. Fert. 22, 303.

Knobil, E., Kostyo, J. L. \& Greep, R. O. (1959) Production of ovulation in the hypophysectomized rhesus monkey. Endocrinology, 65, 487.

Mastroianni, L. \& Rosseau, G. H. (1965) Influence of the intrauterine coil on ovum transport and sperm distribution in the monkey. Am. F. Obstet. Gynec. 93, 416.

Simpson, M. E. \& VAN WAGENEN, G. (1962) Induction of ovulation with human urinary gonadotrophins in the monkey. Fert. Steril. 13, 140.

van WAgenen, G. (1968) Induction of ovulation in Macaca mulatta. Fert. Steril. 19, 15.

van Wagenen, G. \& Simpson, M. E. (1957) Induction of multiple ovulation in the rhesus monkey (Macaca mulatta). Endocrinology, 61, 316. 